Rev. Fac. Agron. (LUZ). 2020, 37: 327-346. Octubre-Diciembre.

DOI: https://doi.org/10.47280/RevFacAgron(LUZ).v37.n4.01

ISSN 2477-9407

\title{
Spray drift with several nozzles under wind breeze in a vineyard nursery
}

Deriva de la aspersión con diferentes boquillas por la acción del viento en un vivero de vid

\section{Depósitos de deriva com diferentes pontas de pulverização sob condição de vento em videira}

\section{Ian Homer Bannister ${ }^{1 *}$, Mayerly Prieto Varón² y Verónica Diaz Martínez ${ }^{3}$}

Coll. Agronomic Scs, University of Chile, Santa Rosa 11315, La Pintana, Santiago, Chile. Postal code 8820808. Correo electronico: (IH) ihomer@ uchile.cl, (D); (MP) mayerlyprieto@uchile.cl, (D); (VD) vdiaz@uchile.cl, (D.

\begin{abstract}
The area planted with grapes in Chile has grown nearly $50 \%$ in the last 12 years, causing a drastic increase in use of agrichemicals. In particular, herbicides need to be applied more precisely to reach the desired targets. Weeds are a limiting factor in nurseries, mostly because of the reduced distance between rows. The spray nozzles are of vital importance because they distribute the mixture over the target. A comparative study between conventional extended rage flat spray (XR) and drift reducing nozzles (TT, DG and AI) was conducted in Vitis vinifera L. cv. Thompson Seedless plants self-rooted in the nursery, studying the drift detection and quantification, of a 5.8 $\mathrm{km} . \mathrm{h}^{-1}$ wind breeze, using the food tracer Brilliant Blue FD \& C-1. Under this breeze condition, at the plants level, the drops produced with the XR nozzle suffered a trajectory deviation. A strong decrease in the spray deposits occurred while the spray area distance increased. At ground level, it was appreciated that with wind conditions, there is an increase in all the nozzles of the tanks before the plant, next to it, and after cultivation, but these did not become statistically significant at this wind level
\end{abstract} Keywords: reducing nozzles, tracer, quality application.

\section{Resumen}

El cultivo vitivinícola en Chile ha crecido el $50 \%$ en los últimos 12 años, provocando un aumento drástico en el uso de agroquímicos, entre ellos los

Recibido el 31-03-2020 • Aceptado el 05-06-2020.

*Autor de correspondencia. Correo electrónico: ihomer@uchile.cl 
herbicidas, los cuales deben ser aplicados en forma dirigida. Las malezas son un factor limitante en el desarrollo del cultivo, y las aplicaciones de herbicidas en viveros a campo libre presentan grandes desafíos para el agricultor sobre todo el distanciamiento entre hilera reducido. Es por esto que disminuir efecto de deriva se hace de suma importancia. Se realizó un estudio comparativo de boquillas tipo abanico plano rango extendido (XR) y tres boquillas de nueva generación: preorificio (DG), cámara de turbulencia (TT) e inducción de aire (AI). Los ensayos se realizaron mediante la simulación de viento de $5,8 \mathrm{~km} . \mathrm{h}^{-1}$ y ausencia de éste, en plantas de vivero de Vitis vinifera L. cv. Thompson Seedless autoenrraizadas en condiciones de campo. Se evaluó la detección y cuantificación de la deriva mediante el uso del trazador Azul Brillante (FD \& C-1). Bajo estas condiciones de aplicación, a nivel planta, la presencia de viento genera una desviación en la trayectoria de las gotas con la boquilla XR. A nivel de suelo se apreció una marcada disminución de los depósitos de aspersión a medida que aumenta la distancia de la zona de aplicación, y en condición de viento, hay un aumento en todas las boquillas de los depósitos previo a la planta, junto a ella, y después del cultivo, pero estos no llegaron a ser significativos estadísticamente a este nivel de viento

Palabras clave: boquillas antideriva, trazadores, calidad aplicación.

\section{Resumo}

O cultivo vitivinícola no Chile cresceu $50 \%$ nos últimos 12 anos, provocando um aumento drástico no uso de agroquímicos, entre eles os herbicidas, os quais devem ser aplicados na forma dirigida. As plantas invasoras são um fator limitante no desenvolvimento do cultivo, sendo aplicações de herbicidas em viveiros a campo livre apresentam grandes desafios para o agricultor como a redução da distância entre hileias. Por isto, a importância de buscar alternativas que permitam diminuir o efeito da deriva. Realizou-se um estudo comparativo de pontas tipo leque plano convencional de faixa ampliada (XR) e três pontas da nova geração, correspondentes ao tipo pré-orifício (DG), pré-orifício com câmara de turbulência (TT), e de indução de ar (AI). Os ensaios se realizaram mediante a simulação de uma condição de vento de $5,8 \mathrm{~km} \cdot \mathrm{h}^{-1}$ e a ausência deste, em plantas de viveiro de Vitis vinifera L. cv. Thompson Seedless, autoenraizadas em condições de campo. Avaliou-se a detecção e quantificação da deriva mediante o uso do traçador Azul Brilhante (FD \& C-1). Sob estas condições de aplicação o aumento da velocidade do vento de $5,8 \mathrm{~km} \cdot \mathrm{h}^{-1}$ gerou um desvio na trajetória das gotas com a ponta XR. No nível do solo, apresenta uma significativa diminuição dos depósitos de aspersão à medida que aumenta a distância da zona de aplicação, e com as condições do vento, há um aumento em todos os bicos dos traços antes da planta, ao lado dela, e após o cultivo, mas estes não se tornaram estatisticamente significativos a este nível de vento.

Palavras chave: deriva, qualidade da aplicação, viveiro vitivinícola, traçadores. 
Rev. Fac. Agron. (LUZ). 2020, 37: 327-346. Octubre-Diciembre.

Homer et al.

\section{Introduction}

At present, vineyards are the most widespread orchard in Chile, with $\sim 70$ varieties grown for fresh fruit consumption, wine and pisco production. The 2008 vineyard census determined that there are $182,660.7$ ha in Chile, twice the area cultivated in 1996, 55,119.4 ha, for fresh consumption, mainly Thompson Seedless (21,243 ha) (ODEPA, 2017).

Weeds are one of the main factors affecting vineyards productivity and area cultivated (Prodanova-Marinova and Koňova, 2016; VCE, 2007), because they compete with the vines for nutrients, water and light, which results in yield losses. They also provide shelter and food to insects and diseases that increase damage (Dami et al., 2005, Linjian et al., 2008). Damage increases in nurseries due to the smaller vines and the high planting density (Dami et al., 2005, Ormeño, 2005).

Among the weeds in vineyard nurseries, those perennials are the main problem, because they live for several seasons, surviving the winter as vegetative propagules, among which rhizomes, tubers, pivotal roots, and stolons stand out (ProdanovaMarinova et al., 2019; ProdanovaMarinova and Koňova, 2016) as they are protected by soil, foliage and debris (Dami et al., 2005).

Also, it is difficult to eliminate perennial weeds in just one season, mainly because of their propagation characteristics and the use of agriculture machinery that help spread them significantly, in

\section{Introducción}

En la actualidad, los viñedos son el cultivo más extendido en Chile, con aproximadamente 70 variedades cultivadas para consumo de fruta fresca, así como para la producción de vino y pisco. El censo de viñedos de 2008 determinó que hay 182.660,7 ha en el país, el doble del área cultivada en 1996, la cual alcanzaba alrededor de $55.119,4$ ha, de las cuales alrededor de 21.243 ha estaban plantadas con el cultivar Thompson Seedless, principalmente para consumo fresco (ODEPA, 2017).

Las malezas son uno de los principales factores que afectan la productividad de los viñedos (Prodanova-Marinova y Koňova, 2016; VCE, 2007), porque compiten por nutrientes, agua y luz, lo que resulta en pérdidas de rendimiento para el cultivo. También son hospederos de insectos y enfermedades (Dami et al., 2005, Linjian et al., 2008). El daño por ataque de insectos y patógenos aumenta en los viveros, debido al poco desarrollo de las plantas y a la alta densidad de siembra (Dami et al., 2005, Ormeño, 2005).

En los viveros de vid, las malezas perennes son el principal problema, porque sobreviven a distintas estaciones, incluso al invierno, como propágulos vegetativos, entre los que se destacan los rizomas, tubérculos, raíces pivotantes y estolones (Prodanova-Marinova et al., 2019; Prodanova-Marinova y Koňova, 2016) que están protegidos por el suelo, el follaje y los residuos (Dami et al., 2005). 


\section{Rev. Fac. Agron. (LUZ). 2020, 37: 327-346. Octubre-Diciembre.}

Homer et al.

particular due to their predominant vegetative propagation (ProdanovaMarinova et al., 2019; ProdanovaMarinova and Koňova, 2016; Dami et al., 2005). Therefore, the proper use of herbicides applied to foliage and translocate to active growth points is key to their successful control.

The effectiveness of the use of herbicides in wine nurseries depends on many factors, such as the timing of application, the spray type, and the equipment and calibration (Arvidsson, et al., 2011; Butts et al., 2018; Jensen et al., 2013). Spraying must be done uniformly, to deposit the product on the weed with minimum drift loss, as an uneven distribution on the foliage and a high drift loss lead to inadequate weed control that will require subsequent spray, and increase control costs (Ozkan and Zhu, 2016). Another serious problem caused by poor herbicide application is plant toxicity, which causes a decrease in plant vigor and yield (ProdanovaMarinova et al., 2019; ProdanovaMarinova and Koňova, 2016).

Glyphosate is the most used herbicide to control perennial weeds in orchards and fruit nurseries in Chile (Kogan and Zuñiga 2001; ODEPA, 2017) because it is translocated to different parts of the weeds, besides being a non-selective herbicide, thus it affects most weeds and is degraded quickly by microorganisms (60 days half-life) in the soil (Bradford and Calvin 2001, Ormeño 2005).

The lesions caused by glyphosate are very similar to those of growthregulating herbicides (Dami et al. 2005), that usually appear around
Además, es difícil eliminar las malas hierbas perennes en solo una temporada, principalmente debido a sus características de propagación y al uso de maquinaria agrícola que ayuda a esparcir principalmente sus propágulos vegetativos (ProdanovaMarinova et al., 2019; ProdanovaMarinova y Koňova, 2016; Dami et al., 2005). Por lo tanto, el uso adecuado de herbicidas aplicados al follaje para su translocación a los puntos de crecimiento activos es clave para el control exitoso de las malezas.

La efectividad del uso de herbicidas en viveros de vid depende de muchos factores, como el momento de la aplicación, el tipo de rociado, el equipo y su calibración (Arvidsson, et al., 2011; Butts et al., 2018; Jensen et al., 2013). La aspersión debe hacerse de manera uniforme, para depositar el producto en la maleza con una pérdida de deriva mínima, ya que una distribución desigual en el follaje y una alta pérdida de deriva conducen a un control inadecuado de la maleza, requiriendo una aspersión posterior, lo cual aumentaría los costos del control fitosanitario (Ozkan y Zhu, 2016). Otro problema grave causado por la aplicación deficiente de herbicidas es su toxicidad para las plantas, provocando una disminución en el vigor y el rendimiento del cultivo (Prodanova-Marinova et al., 2019; Prodanova-Marinova y Koňova, 2016).

El glifosato es el herbicida más utilizado para controlar las malas hierbas perennes en huertos $\mathrm{y}$ viveros de frutales en Chile (Kogan y Zuñiga 2001; ODEPA, 2017). Este herbicida sistémico, no selectivo, es 
two week after contact, and generate new deformed and chlorotic leaves, that may appear long and wrinkled; the shoot growth also die. In severe cases, vines may die or delay severely their growth (Prodanova-Marinova et al., 2019; Prodanova-Marinova and Koňova, 2016). Recovery from a serious injury is slow and in extreme cases may take over a year (Dami et al., 2005). In white wine vine nurseries such as Thompson Seedless, plant toxicity is more noticeable.

In nursery plantations, high planting density, with a short distance between rows, poor application of chemicals can cause serious damage, especially in windy conditions, where drift is the main cause of herbicide damages to the vines, a factor that also limits the time available for the sprays.

Drifting of the product in the air during and after spray means that it does not reach the target and contaminate the environment (Ozkan and Zhu, 2016), Villalba and Hetz 2010). Drift losses vary from 1 to 30 $\%$ of the amounts applied, depending on the conditions at the time of application relative to drop size, spray technique, topography and weather conditions, among others (Villalba and Hetz, 2010). Approximately half of the drift deposits occur in the first $8 \mathrm{~m}$ in favor of the wind and decrease very rapidly with distance (Bode 1984).

Tests in the laboratory at $24{ }^{\circ} \mathrm{C}$ with $100 \mu \mathrm{m}$ at a $5.18 \mathrm{~km} \cdot \mathrm{h}^{-1}$ air flow carried residues up to $10 \mathrm{~m}$, and $35 \mathrm{~m}$ at $25.8 \mathrm{~km} \cdot \mathrm{h}^{-1}$ (Hardi 2003).

Droplet size is the main factor of drift in herbicide sprays, but there translocado a diferentes partes de las malas hierbas, por lo que controla la mayoría de las malezas y se degrada rápidamente en el suelo por acción de los microorganismos (60 días de vida media) (Bradford y Calvin 2001, Ormeño 2005).

Las lesiones causadas por el glifosato son muy similares a las de los herbicidas que regulan el crecimiento (Dami et al. 2005), que generalmente aparecen alrededor de dos semanas después del contacto y generan nuevas hojas deformadas (largas y arrugadas) y cloróticas. El crecimiento del brote también se detiene. En casos severos, las vides pueden morir o retrasar severamente su crecimiento (Prodanova-Marinova et al., 2019; Prodanova-Marinova y Koňova, 2016). La recuperación de una lesión grave es lenta y en casos extremos puede llevar más de un año (Dami et al., 2005). En viveros de vid para vinos como Thompson Seedless, la toxicidad de las plantas es más notable.

La alta densidad de siembra en los viveros de vid, con una corta distancia entre hileras, la mala aplicación de productos químicos puede causar daños graves, especialmente en condiciones de viento, donde la deriva es la principal causa de daños en el cultivo por herbicidas. El viento también es un factor que limita el momento y tiempo disponible para realizar las aspersiones.

La deriva del producto en el aire durante y después del rociado significa que no alcanza el objetivo y contamina el medio a mbiente (Ozkan y Zhu, 2016), Villalba y Hetz 2010). Las pérdidas por deriva varían del 1 al $30 \%$ de las 
is different size recommendation to reduce drift, like over $100 \mu \mathrm{m}$ (Mota, 2015; Oliveira and Antuniassi, 2012; Villalba and Hertz, 2010), larger than 200 micron diameter may be needed to satisfactorily reduce drift (Boller and Schlosser, 2010; Ozkan and $\mathrm{Zhu}, 2016)$. However, the increase in droplet size by reducing spray pressure is commonly used to reduce drift (Behmer et al., 2010; Bradford and Calvin, 2001; Garcerá et al., 2017; Planas et al., 2013; Van de Zande et al., 2012). Thus, nozzles designed to produce large droplets without changing the flow rate (volume rate) are of great importance.

Herein, we evaluated and quantified spray deposits on vine leaves with different nozzles, using the FD \& C-1 Brilliant Blue food tracer, in the presence and absence of wind.

\section{Materials and methods}

Thompson Seedless table grape plants (Vitis vinifera L.) auto-rooted under nursery conditions were used. The trials were carried out in February 2012, at a nursery in the Metropolitan Region, Santiago, Chile $\left(33.20^{\circ} \mathrm{S}, 70.50^{\circ} \mathrm{W}\right)$.

Sprays were done at $10 \mathrm{AM}$ onto the nursery plants under a $5.8 \mathrm{~km} \cdot \mathrm{h}^{-1}$ breeze (measured with a manual La Crosse Technology EA 3010U windmeter) at vine level using a 44 $\mathrm{cm}$ diameter $180 \mathrm{~W}$ industrial Famasol (Santiago, Chile) F70 fan adapted to a Staco Inc. frequency inverter. Also, a semi-tunnel $80 \mathrm{~cm}$ deep and $60 \mathrm{~cm}$ high PVC tube was attached to the fan cantidades aplicadas, dependiendo de las condiciones en el momento de la aplicación en relación con el tamaño de la gota, la técnica de pulverización, la topografía y las condiciones climáticas, entre otros (Villalba y Hetz, 2010). Aproximadamente la mitad de los depósitos de deriva ocurren en los primeros $8 \mathrm{~m}$ a favor del viento $\mathrm{y}$ disminuyen muy rápidamente con la distancia (Bode 1984).

Las pruebas de laboratorio a 24 ${ }^{\circ} \mathrm{C}$ para la aspersión de una solución con un tamaño de gota de $100 \mu \mathrm{m}$ de diámetro, el flujo de aire de $5,18 \mathrm{~km}$.h 1 transportó los residuos a $10 \mathrm{~m}$ de distancia, en tanto que a una velocidad de $25,8 \mathrm{~km} \cdot \mathrm{h}^{-1}$ los residuos llegaron hasta una distancia de dispersión de $35 \mathrm{~m}$ (Hardi 2003).

El tamaño de la gota es el principal factor de deriva en las aspersiones de herbicidas. Hay diferentes recomendaciones de tamaño de gota en las aspersiones para reducir la deriva, como por ejemplo, un diámetro de gota mayor que $100 \mu \mathrm{m}$ (Mota, 2015; Oliveira y Antuniassi, 2012; Villalba y Hertz, 2010), o mayor de 200 micras (Boller y Schlosser, 2010; Ozkan y Zhu, 2016). Para reducir la deriva es común el aumento en el tamaño de las gotas y reducir la presión de aspersión (Behmer et al., 2010; Bradford y Calvin, 2001; Garcerá et al., 2017; Planas et al., 2013; Van de Zande et al., 2012). Por lo que, boquillas diseñadas para producir gotas grandes sin cambiar el caudal de descarga de la asperjadora son de gran importancia.

En este trabajo se evaluó y cuantificó los depósitos de las derivas producidas en las aspersiones foliares 
Rev. Fac. Agron. (LUZ). 2020, 37: 327-346. Octubre-Diciembre.

Homer et al.

directed to the plants, and protection screens were set to avoid the effect of wind blasts and possible drifts to side treatments.

For the spraying, the conventional nozzle extended range (XR) and three anti-drift nozzles, the pre-orifice (DG), pre-orifice with turbulence chamber or turbo type (TT), and air induction (AI) were used (Spraying Systems $\left.{ }^{\circledR}\right)$, with a flat fan type and a $110^{\circ}$ application angle, and a $0.76 \mathrm{~L}^{\mathrm{min}}{ }^{-1}$ flow rate, and a volume median diameter (VMD) of $114-235 \mu \mathrm{m}$ for XR; $236-340 \mu \mathrm{m}$ to DG and TT, and finally, $404-502$ $\mu \mathrm{m}$ for AI (TeeJet, 2014). The sprays were done at morning hours, using a Solo® 425 lever type back sprayer at a 3 bar and $35 \mathrm{~cm}$ height. A Volume rate of 150 L.ha $^{-1}$, a displacement speed of $40 \mathrm{~m} \mathrm{~min}^{-1}$ and a $90 \mathrm{~cm}$ working width, corresponding to the width of the nursery inter-row, were used.

A complete $4 \times 2$ random block factorial experiment design was used, corresponding to the 4 sprays with the different nozzles, in the presence and absence of wind, with four replicates per treatment. The experimental unit were 5 Thompson Seedless vine plants, of which the three central plants were used for evaluations. The statistical analysis used 4 replicates, and the Di Rienzo, Guzmán y Casanoves test (DGC, $\mathrm{p} \leq 0.05$ ) was used to compare the media, using the InfoStat program.

Evaluation of drift deposits on plants

To evaluate spray deposits under the drift and without it, distilled water and the FD \& C-1 Bright Blue food tracer were used at $500 \mathrm{mg} . \mathrm{L}^{-1}$, following Palladini et al. (2005). After del cultivo de la vid, utilizando diferentes boquillas de aspersión, utilizando el colorante de alimentos FD \& C-1 Brilliant Blue (azul brillante en presencia y ausencia de viento.

\section{Materiales y métodos}

Se utilizaron plantas de uva de mesa (Vitis vinifera L.) cv. Thompson Seedless propagadas en vivero. Los ensayos se llevaron a cabo en febrero de 2012, en un vivero en la Región Metropolitana de Santiago, Chile $\left(33,20^{\circ} \mathrm{S}, 70,50^{\circ} \mathrm{W}\right)$.

Las aspersiones se realizaron a las 10 am en las plantas de vivero bajo condiciones de viento de $5,8 \mathrm{~km} . \mathrm{h}^{-1}$ (medida con un medidor de viento manual La Crosse Technology EA 3010U) a nivel del cultivo, utilizando un ventilador F70 industrial Famasol (Santiago, Chile) de $44 \mathrm{~cm}$ de diámetro y $180 \mathrm{~W}$, adaptado a un inversor de frecuencia Staco Inc. Además, se colocó un tubo de PVC de semi-túnel de $80 \mathrm{~cm}$ de profundidad y $60 \mathrm{~cm}$ de alto al ventilador dirigido a las plantas y se instalaron pantallas de protección para evitar el efecto de las ráfagas de viento y las posibles derivaciones a los tratamientos laterales.

Para la aspersión, se utilizaron boquillas convencionales de rango extendido (XR) y tres boquillas de reducción de deriva, con preorificio (DG), con preorificio y cámara de turbulencia o tipo turbo (TT) y de inducción de aire (AI). (Spraying Systems ${ }^{\mathbb{R}}$, con un tipo de descarga en forma de abanico plano, un ángulo de aplicación de $110^{\circ}$, caudal de 0,76 
Rev. Fac. Agron. (LUZ). 2020, 37: 327-346. Octubre-Diciembre.

Homer et al.

ISSN 2477-9407

spraying, 10 leaves per treatment were removed and stored in darkness in individual marked polyethylene bags. Once in the laboratory the samples were washed with $20 \mathrm{~mL}$ distilled water to remove the tracer; the washed out dilutions were stored at room temperature under dark in 50 $\mathrm{mL}$ plastic containers until absorbance was read in a spectrophotometer, following Villalba et al. (2009).

The solution deposits on the leaves were determined using a UV-Vis T70 spectrophotometer ( $\mathrm{PG}$ Instruments Ltd.) at $630 \mathrm{~nm}$ (Palladini et al., 2005; Villalba et al., 2009). The readings were adjusted to a calibration curve obtained previously, and the residues deposited $(\mathrm{mL})$ in each treatment were calculated with the equation:

$\mathrm{C} 1 \times \mathrm{V} 1=\mathrm{C} 2 \times \mathrm{V} 2$

Where

$\mathrm{C} 1$ = Concentration of the dye (mg.L $\left.\mathrm{L}^{-1}\right)$ at application.

$\mathrm{V} 1=$ Residue $(\mathrm{mL})$ deposited on the leaves.

$\mathrm{C} 2=$ Concentration in the sample (500 mg.L $\mathrm{L}^{-1}$ ).

V2= Distilled water used to wash the leaves $(20 \mathrm{~mL})$.

Leaves sampled at random were scanned to determine their area with the IMG Tool 2.0 program, to relate the volume of the solution deposited on the leaves with the respective leaf area.

\section{Evaluation drift deposits on artificial targets}

To evaluate drift deposits, 5 Petri dishes were set horizontally in the middle of the plants (3 dishes in the application line and 2 behind the plants) and another 2 vertically on a
L.min ${ }^{-1}$ y un diámetro medio volumétrico (VMD) de: $114-235 \mu \mathrm{m}$ para XR, 236 - $340 \mu \mathrm{m}$ para DG y TT, y 404 - $502 \mu \mathrm{m}$ para AI (TeeJet, 2014). Las aspersiones se realizaron en las horas matutinas, utilizando un asperjadora de espalda marca Solo ${ }^{\mathbb{R}}$ 425 con una presión de descarga de 3 bar y altura de descarga de $35 \mathrm{~cm}$. Se utilizó una dosis de 150 L.ha-1, una velocidad de desplazamiento de $40 \mathrm{~m} \cdot \mathrm{min}^{-1}$ y un ancho de trabajo de $90 \mathrm{~cm}$, correspondiente al ancho de la hilera entre viveros.

Se utilizó un diseño de experimento con arreglo factorial $4 \times 2$ en bloques completos al azar, siendo los tratamientos evaluados los 4 tipos de aspersiones con las diferentes boquillas, en presencia y ausencia de viento. Se hicieron cuatro repeticiones por tratamiento. La unidad experimental fueron 5 plantas de vid del cultivar Thompson Seedless, de las cuales fueron seleccionadas para las evaluaciones, las tres plantas centrales del bloque. Para el análisis estadístico de comparación de las medias de los tratamientos se aplicó la prueba de Di Rienzo, Guzmán y Casanoves (DGC, $\mathrm{p} \leq 0,05$ ), utilizando el programa InfoStat.

Evaluación de los depósitos de las aspersiones en el cultivo

Para evaluar los depósitos con y sin efecto de la deriva eólica de las aspersiones, se utilizó el colorante de alimentos azul brillante FD \& C-1 a una dosis de $500 \mathrm{mg} . \mathrm{L}^{-1}$ diluido en agua destilada, siguiendo el método descrito por Palladini et al. (2005). Después de la aspersión, se retiraron 10 hojas por tratamiento y se almacenaron en 
Rev. Fac. Agron. (LUZ). 2020, 37: 327-346. Octubre-Diciembre.

Homer et al.

metal support at 25 and $50 \mathrm{~cm}$ above the ground, with 2 replicates per experiment unit. The position of the dishes is presented in table 1 and Figure 1, with a reference number (1 to 7$)$. la oscuridad, en bolsas de polietileno marcadas individualmente. Una vez en el laboratorio, las muestras se lavaron con $20 \mathrm{~mL}$ de agua destilada para extraer el marcador de las hojas, recogiendo el lavado en recipientes

Table 1. Distribution of the Petri dishes from the vine plants to determine residue deposits.

Cuadro 1. Distribución de las placas de Petri de las plantas de vid para determinar los depósitos de residuos.

\begin{tabular}{|c|c|}
\hline Petri dishes & Distance to the plant $(\mathrm{cm})$ \\
\hline \multicolumn{2}{|c|}{ Horizontal dishes } \\
\hline 1 & 215 \\
\hline 2 & 130 \\
\hline 3 & 00 \\
\hline 4 & -130 \\
\hline 5 & -215 \\
\hline \multicolumn{2}{|c|}{ Vertical dishes* } \\
\hline 6 & 25.0 \\
\hline 7 & 50.0 \\
\hline
\end{tabular}

*Distance from the ground $(\mathrm{cm})$

*Distancia desde el suelo $(\mathrm{cm})$

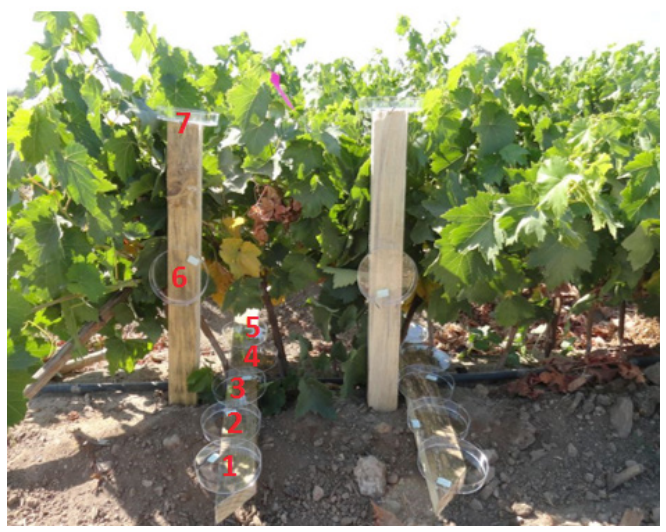

Figure 1. Distribution of the Petri dishes from the vine plants to determine residue deposits.

Figura 1. Distribución de las placas de Petri de las plantas de vid para determinar los depósitos de residuos. 
Sprays were added to the FD \& C-1 bright blue tracer as described. Afterwards, the Petri dishes were washed in the laboratory with $20 \mathrm{~mL}$ distilled water to remove the tracer. These solutions ware stored in $50 \mathrm{~mL}$ plastic containers at room temperature in the dark until reading the absorbance in the spectrophotometer, as indicated, to relate the deposits with their area.

\section{Spray distribution curves}

Considering that only the downwind direction of the application was measured, an additional nozzle bench test was done to determine the characteristic distribution for each nozzle in the absence of wind, to check whether the observed facts of the trial correspond to the drift or the characteristic distribution. The conditions of the trial were the similar with a duration of $30 \mathrm{sec}$ at 3 bar and $35 \mathrm{~cm}$ above the ground.

\section{Results and discussion}

\section{Drift deposits on plants}

The spray deposits on the vine plants indicated statistically significant differences $(p \leq 0.05)$ between nozzle types $(p \leq 0.05)$ but no differences for wind effect at $5.8 \mathrm{~km} \cdot \mathrm{h}^{-1}$, except XR (Figure 2). The spray with the conventional nozzle (XR) produced the greatest deposits on the vine leaves $\left(1.48 \mu \mathrm{g} . \mathrm{cm}^{-2}\right)$ in comparison with the anti-drift nozzles, possibly because of a decrease in droplet size, which makes them more susceptible to wind drift, thus increasing deposit of the tracer on the plants, in agreement with Wolf and Frohberg (2002). de plástico de $50 \mathrm{~mL}$, almacenándolo a temperatura ambiente en la oscuridad, hasta que se leyó la concentración del colorante aplicado en un espectrofotómetro, siguiendo la metodología descrita por Villalba et al. (2009).

Los depósitos de solución en las hojas se determinaron utilizando un espectrofotómetro UV-Vis T70 (PG Instruments Ltd.) a $630 \mathrm{~nm}$ (Palladini et al., 2005; Villalba et al., 2009). Las lecturas se ajustaron a una curva de calibración obtenida previamente, y los residuos depositados $(\mathrm{mL})$ en cada tratamiento se calcularon con la ecuación:

$$
\mathrm{C} 1 \mathrm{x} \text { V1 = C2 x V2 }
$$

Dónde

$\mathrm{C} 1$ = Concentración del colorante (mg.L ${ }^{-1}$ ) en la hoja.

$\mathrm{V} 1$ = Residuo $(\mathrm{ml})$ depositado en las hojas.

$\mathrm{C} 2=$ Concentración total del colorante aplicado (500 mg.L $\left.\mathrm{L}^{-1}\right)$.

V2 = Volumen de lavado de hojas (20 mL de agua destilada).

Las hojas muestreadas al azar se escanearon para determinar su área foliar con el programa IMG Tool 2.0, para relacionar el volumen de la solución depositada en las hojas con el área foliar respectiva.

Evaluación de los depósitos de las aspersiones sobre objetivos artificiales

Para evaluar los depósitos con y sin efecto de la deriva eólica de las aspersiones, se colocaron 5 placas de Petri en el medio de las plantas (3 placas en la línea de aplicación y 2 detrás de las plantas) y otras 2 sobre un soporte de metal a 25 y $50 \mathrm{~cm}$ del suelo, con 2 réplicas por unidad 
Rev. Fac. Agron. (LUZ). 2020, 37: 327-346. Octubre-Diciembre.

Homer et al.

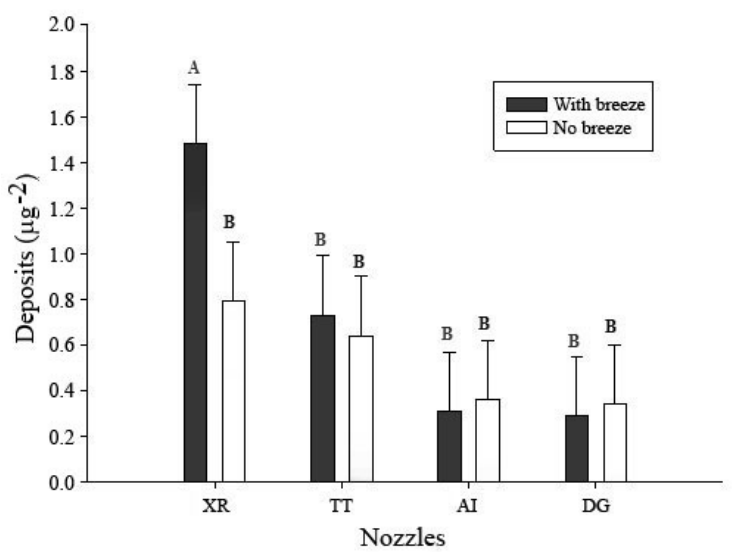

Figure 2. Interaction between breeze and nozzles types in spray deposits on vine plants. Different letters indicate signicant differences $(p \leq 0.05)$ in the DGC test.

Figura 2. Interacción entre el viento y los tipos de boquillas en los depósitos de la aspersión en plantas de vid. Letras diferentes indican diferencias signicativas $(\mathrm{p} \leq 0,05)$ para la prueba DSG.

These results indicate that in normal conditions, all the nozzles had a similar effect of deposits, but with breeze during the spray, antidrift nozzles did not increase as much their drift as the conventional (XR), generate a deviation in the trajectory of the smaller drops. Similar results were found by Wolf and Frohberg (2002), and Miller et al. (2001), who pointed out that under breeze conditions droplet size increases. In addition, Villalba and Hetz (2010) reported 1 to $31 \%$ losses in the amounts applied with conventional nozzles under breeze at spraying.

Wolf and Frohberg (2002) observed in a wind tunnel, that XR created significantly more drift than TT, and DR and AI were not experimental. La posición de las placas se presenta en el Cuadro 1 y en la Figura 1, con un número de referencia (1 a 7 ).

Se utilizó el marcador FD \& C-1 Brilliant Blue (azul brillante) en la solución asperjada, como se describió anteriormente. Posteriormente, las placas de Petri se lavaron en el laboratorio con $20 \mathrm{~mL}$ de agua destilada para recoger el marcador en recipientes de plástico de $50 \mathrm{~mL}$, que fueron almacenados a temperatura ambiente en la oscuridad, hasta leer la medida de la concentración del colorante en un espectrofotómetro, siguiendo el procedimiento explicado en la sección anterior. Se hizo la relación de la concentración de la solución con el área de aspersión, tal como se describió previamente. 
Rev. Fac. Agron. (LUZ). 2020, 37: 327-346. Octubre-Diciembre.

Homer et al.

ISSN 2477-9407

significantly, but did produce less drift than XR and TT.

\section{Drift deposits on artificial targets}

Horizontal drifting. The spray deposits in the Petri dishes presented statistically significant differences $(p \leq 0.05)$ only between the interaction of the nozzle effect and the position of the dishes (Figure $3)$. Although there is an increase in deposits in the wind versus no wind condition, and therefore drift, these are not statistically significant. If analyzed independently by plate, only wind TT, showed no differences between the plates, while the rest showed the expected behavior it presented a statistical significant gradual decrease in spray deposits on the evaluated dishes were moved away from the spray midline (table 2).

Table 2. Effect of application with and without wind on the tracer

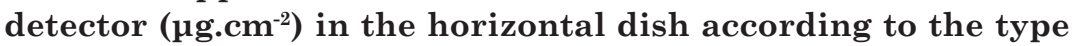
of nozzle.

Cuadro 2. Efecto de la aplicación con y sin viento sobre los depósitos del marcador $\left(\mu \mathrm{g} . \mathrm{cm}^{-2}\right)$ según el tipo de boquilla.

\begin{tabular}{|c|c|c|c|c|c|c|c|c|c|c|c|c|c|c|c|c|}
\hline & \multicolumn{3}{|c|}{$\mathrm{XR}$} & \multicolumn{4}{|c|}{$\mathrm{TT}$} & \multicolumn{4}{|c|}{ DG } & \multicolumn{5}{|c|}{$\mathrm{TT}$} \\
\hline & $\begin{array}{c}\text { No } \\
\text { breeze }\end{array}$ & & $\begin{array}{c}\text { With } \\
\text { breeze }\end{array}$ & & $\begin{array}{c}\text { No } \\
\text { breeze }\end{array}$ & & $\begin{array}{c}\text { With } \\
\text { breeze }\end{array}$ & & $\begin{array}{c}\text { No } \\
\text { breeze }\end{array}$ & & $\begin{array}{c}\text { With } \\
\text { breeze }\end{array}$ & & $\begin{array}{c}\text { No } \\
\text { breeze }\end{array}$ & & $\begin{array}{c}\text { With } \\
\text { breeze }\end{array}$ & \\
\hline Dish & Means & & Means & & Means & & Means & & Means & & Means & & Means & & Means & \\
\hline 1 & 0.70 & $\mathrm{a}$ & 0.86 & $\mathrm{a}$ & 0.7 & $\mathrm{a}$ & 0.67 & $\mathrm{a}$ & 1.22 & $\mathrm{a}$ & 1.39 & $\mathrm{a}$ & 1.28 & $\mathrm{a}$ & 1.72 & a \\
\hline 2 & 0.60 & $\mathrm{a}$ & 0.73 & $\mathrm{a}$ & 0.67 & $\mathrm{a}$ & 0.57 & $\mathrm{a}$ & 0.84 & $\mathrm{~b}$ & 1.06 & $\mathrm{~b}$ & 1.45 & $\mathrm{a}$ & 1.37 & a \\
\hline 3 & 0.50 & $\mathrm{a}$ & 0.6 & $\mathrm{~b}$ & 0.48 & $\mathrm{~b}$ & 0.55 & $\mathrm{a}$ & 0.35 & $\mathrm{c}$ & 0.60 & $\mathrm{c}$ & 1.16 & $\mathrm{a}$ & 0.86 & $b$ \\
\hline 4 & 0.14 & $\mathrm{~b}$ & 0.27 & $\mathrm{c}$ & 0.14 & $\mathrm{~b}$ & 0.33 & $\mathrm{a}$ & 0.01 & $d$ & 0.09 & $d$ & 0.38 & $\mathrm{~b}$ & 0.25 & $\mathrm{c}$ \\
\hline 5 & 0.04 & $\mathrm{~b}$ & 0.03 & $\mathrm{c}$ & 0.04 & $\mathrm{~b}$ & 0.43 & $\mathrm{a}$ & 0.01 & $d$ & 0.02 & $\mathrm{~d}$ & 0.07 & $\mathrm{~b}$ & 0.15 & $\mathrm{c}$ \\
\hline
\end{tabular}

Different verticals letters indicate, significant differences $(\mathrm{p} \leq 0.05)$, according to a DGC test.

Diferentes letras indican diferencias significativas $(\mathrm{p} \leq 0.05)$, para la prueba DGC.
Curvas de distribución de aspersión

Teniendo en cuenta que solo se midió la dirección del viento hacia abajo de la aplicación, se realizó una prueba de banco de boquillas adicional para determinar la distribución característica de cada boquilla en ausencia de viento $\mathrm{y}$ verificar si los hechos observados del ensayo corresponden a la deriva o la distribución característica de la solución. Las condiciones de la prueba fueron similares con una duración de 30 s a una presión de 3 bar y a una altura de $35 \mathrm{~cm}$ por encima del suelo.

\section{Resultados y discusión}

\section{Depósitos de las aspersiones en el}

Los depósitos de las aspersiones en las plantas de vid indicaron diferencias 
As expected, all the nozzles presented a gradual decrease in spray deposits on the evaluated dishes were moved away from the spray midline.

The deposits collected on the Petri dishes for each nozzle type is presented in Figure 3. At the first evaluation, a point at $21.5 \mathrm{~cm}$ from the plant (at sprayed band), statistically significant differences occurred between the treatments $(p \leq 0.05)$. The sprays with the AI and DG nozzles had the greatest deposits (1.5 and 1.3 jg.cm ${ }^{-2}$, respectively), possibly because these nozzles produce the largest droplets (544 and $329 \mu \mathrm{m}$, respectively), followed by the sprays with the XR

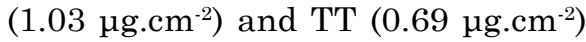
nozzles. estadísticamente

significativas $(p \leq 0,05)$ entre los tipos de boquillas, aunque no hubo diferencias para el efecto del viento a $5,8 \mathrm{~km} . \mathrm{h}^{-1}$, excepto para las aspersiones con la boquilla XR (Figura 2). La aspersión con la boquilla convencional XR produjo los mayores depósitos en las hojas de la vid $\left(1,48 \mu \mathrm{g} . \mathrm{cm}^{-2}\right)$, en comparación con las boquillas anti-deriva evaluadas, posiblemente debido al mayor tamaño de las gotas, haciéndolas menos susceptibles a la deriva por el viento, de acuerdo con Wolf y Frohberg (2002).

Estos resultados indican que, en condiciones normales, todas las boquillas tuvieron un efecto similar sobre los depósitos dejados por las aspersiones, pero con la acción del viento durante la aspersión, las

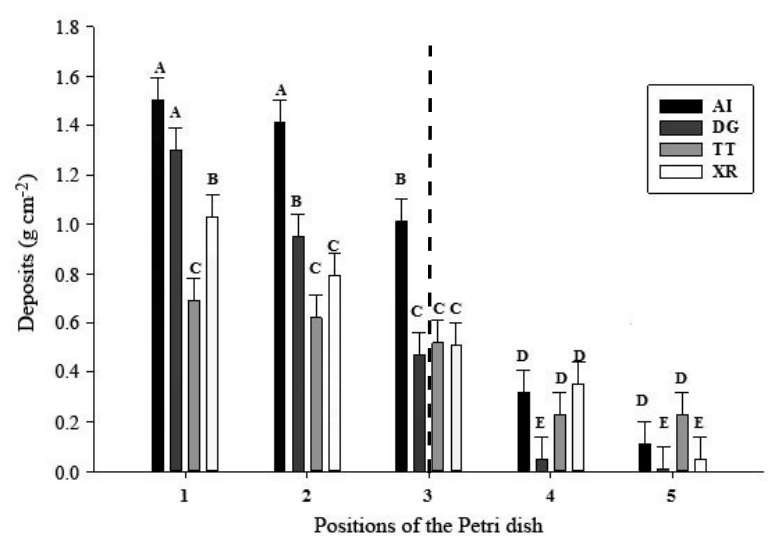

Figure 3. Spray deposits for the interaction between nozzle types and the horizontal position of the Petri dishes. Different letters indicate significant differences $(p \leq 0.05)$ in the DGC test. The vertical segmented lines indicate the dish at plant level.

Figura 3. Depósitos de la aspersión originados por la interacción entre los tipos de boquillas y los diferentes puntos del área de aspersión (capsulas de Petri). Letras diferentes indican diferencias significativas $(\mathrm{p} \leq 0.05)$, para la prueba DSG. La línea segmentada vertical indica el nivel de la capsula de Petri a nivel de la planta. 
On dish 2, border of sprayed band at $13 \mathrm{~cm}$ from the plant in Figure 2, there were statistically significant differences between the treatments, with greater deposits on the spray with the AI nozzle $\left(1.41 \mathrm{\mu g} . \mathrm{cm}^{-2}\right)$, followed by the spray with the DG nozzle $\left(0.95 \mu \mathrm{g} . \mathrm{cm}^{-2}\right)$, and the XR and TT nozzles (0.75 and 0.62 $\mu$ g. $\mathrm{cm}^{-2}$, respectively).

At the third dish point, not at the sprayed band at plant level, statistically significant differences occurred between the treatments, with the AI nozzle producing the greatest deposit $\left(1.0 \mu \mathrm{gg} . \mathrm{cm}^{-2}\right)$ compared to the other treatments. However, no significant differences occurred between the TT, XR, and DG nozzles.

On the fourth dish, at $13 \mathrm{~cm}$ behind the plants, a $37.84 \%$ decrease occurred with dish 3 , possibly due to the barrier effect of the plants at this point. However, no significant differences occurred between the sprays with nozzles AI, TT and XR $\left(0.35,0.32\right.$, and $0.23 \mu \mathrm{g} . \mathrm{cm}^{-2}$; Figure 3). Similar results were obtained by Guler et al., (2007), who pointed out that at a wind speed $>5.0 \mathrm{~km} \cdot \mathrm{h}^{-1}$ produced no significant differences in spray deposits with AI and XR nozzles at $0.8 \mathrm{~m}$ on clear ground. However, the spray with the DG nozzle produced the smallest spray deposit $\left(0.05 \mu \mathrm{g} . \mathrm{cm}^{-2}\right)$.

On the fifth dish, at $21.5 \mathrm{~cm}$ behind the plant, statistically significant differences occurred between treatments, due to bigger deposits of the sprays with the TT and AI nozzles (0.23 and $0.11 \mu \mathrm{g} . \mathrm{cm}^{-2}$, respectively). The sprays with the XR and DG boquillas anti-deriva mostraron una menor deriva eólica en comparación a las boquillas convencionales XR. Wolf y Frohberg (2002) y Miller et al. (2001) encontraron resultados similares, señalando que bajo condiciones de brisa debe aumentarse el tamaño de la gota. Además, Villalba y Hetz (2010) informaron pérdidas de 1 a $31 \%$ en las cantidades aplicadas con boquillas convencionales por efecto del viento durante la aspersión.

Wolf y Frohberg (2002) observaron en un túnel de viento que las boquillas $\mathrm{XR}$ originaron una deriva significativamente mayor que TT, mientras que las derivas originadas por las boquillas DR y AI no mostraron diferencias imporatntes, aunque fueron significativamente menores que las producidas por las boquillas XR y TT.

Depósitos producto de la deriva de las aspersiones sobre objetivos artificiales

Deriva horizontal. Los depósitos de pulverización en las placas de Petri presentaron diferencias estadísticamente significativas $(\mathrm{p} \leq 0,05)$ solo entre la interacción del efecto de la boquilla y la posición de las placas (Figura 3). Aunque hubo un aumento en los depósitos producidos por el viento, en comparación a la ausencia de viento, sin embargo, estas diferencias no fueron estadísticamente significativas. $\mathrm{Al}$ analizar la distribución de la deriva originada por las aspersiones utilizando cada boquilla, solo las aspersiones con la boquilla TT no mostró efecto del viento, mientras que el resto de las boquillas mostró el comportamiento esperado, 
Rev. Fac. Agron. (LUZ). 2020, 37: 327-346. Octubre-Diciembre.

Homer et al.

nozzles produced the least deposits (0.05 and $0.01 \mu \mathrm{g} . \mathrm{cm}^{-2}$, respectively). These results are explained as in the previous statement.

In general, a marked decrease in spray deposits occurred when increasing the distance from the spray nozzle, in agreement with Wolf and Frohberg (2002) and Miller et al. (2001). In dish 4 (13 $\mathrm{cm}$ behind the plant), an $81.1 \%$ reduction of deposits occurred from dish 1.

Vertical drifting. Significant differences $(p \leq 0.05)$ occurred between the two nozzle distances from the ground (25 and $50 \mathrm{~cm}$, Figure 4).

The dish 6 at $25 \mathrm{~cm}$ above the ground presented statistically significant differences $(\mathrm{p} \leq 0.05)$ between the treatments (Figure 4). The greatest spray deposits occurred with the XR and TT nozzles (0.33 and 0.25 $\mu \mathrm{g} . \mathrm{cm}^{-2}$, respectively), followed by the AI and DG nozzles, which produced the smallest deposits (0.16 and 0.02 $\mu$ g. $\mathrm{cm}^{-2}$, respectively). This is mainly due that the AI and DG nozzles reduce the number of fine droplets compared to the standard flat XR nozzle; diminishing the drift effect vertically. Wilson et al., (2008), indicate that the nozzle TT significantly reduces drift compared to the DG nozzle at a 1.03 bar pressure.

On dish 7 at $50 \mathrm{~cm}$ above the ground, no significant differences occurred between the treatments. These results coincide with Guler et al., (2007) in wind tunnels tests with $\mathrm{AI}$ and XR application nozzles at 9 and $18 \mathrm{~km} \cdot \mathrm{h}^{-1}$. However, the least deposit occurred with the DG nozzle (0.02 $\left.\mu \mathrm{g} . \mathrm{cm}^{-2}\right)$. presentando una disminución gradual y estadísticamente significativa en los depósitos originados por las aspersiones, a medida que se alejaban de la línea media de la zona de aplicación (Cuadro 2).

Como se esperaba, todas las boquillas presentaron una disminución gradual en los depósitos acumulados en las cápsulas de Petri, a medida que se alejaban de la línea media de la zona de aspersión.

Los depósitos recogidos en las placas de Petri para cada tipo de boquilla se presentan en la Figura 3. En la primera evaluación, se observaron diferencias estadísticamente significativas entre los depósitos originados por los tratamientos $(\mathrm{p} \leq 0,05)$ a $21,5 \mathrm{~cm}$ de la planta (en la banda rociada). Las aspersiones con las boquillas AI y DG originaron los mayores depósitos (1,5 y 1,3 $\mu_{\text {g.cm }}{ }^{-2}$, respectivamente), posiblemente porque estas boquillas producen las gotas más grandes $(544 \mathrm{y}$ $329 \mu \mathrm{m}$, respectivamente), seguidas de las pulverizaciones con XR (Boquillas $\left.1,03 \mu \mathrm{g} \cdot \mathrm{cm}^{-2}\right)$ y TT $\left(0,69 \mu \mathrm{g} \cdot \mathrm{cm}^{-2}\right)$.

En la placa 2, en el borde de la banda de aspersión, a $13 \mathrm{~cm}$ de la planta (Figura 2), hubo diferencias estadísticamente significativas entre los tratamientos, con mayores depósitos originados por la aspersión con la boquilla AI (1,41 $\left.\mu \mathrm{g} . \mathrm{cm}^{-2}\right)$, seguido del rociado con la boquilla $\mathrm{DG}$ $\left(0,95 \mu \mathrm{g} . \mathrm{cm}^{-2}\right)$ y las boquillas XR y TT (0,75 y $0,62 \mu \mathrm{g} . \mathrm{cm}^{-2}$, respectivamente).

En la placa ubicada en el tercer punto, no en la banda rociada a nivel de la planta, se observaron diferencias estadísticamente significativas en los depósitos originados por cada 
Rev. Fac. Agron. (LUZ). 2020, 37: 327-346. Octubre-Diciembre.

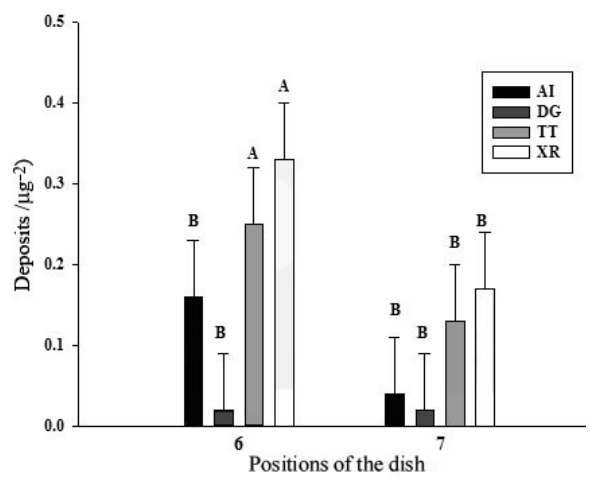

Figure 4. Spray deposits for the interaction between nozzle types and vertical position of the Petri dishes. Different letters indicate significant differences $(\mathrm{p} \leq 0.05)$ in the DGC test.

Figura 4. Depósitos de las aspersiones originados por la interacción entre los tipos de boquillas y las aplicaciones a diferentes alturas. Letras diferentes indican diferencias significativas $(p \leq 0,05)$ para la prueba DSG.

In general, a decrease in spray deposits occurred as dish height increased. Dish 6, at $25 \mathrm{~cm}$ above the ground, a $47.4 \%$ increase occurred with dish 7 at $50 \mathrm{~cm}$ from the ground.

\section{Spray distribution curves}

Although all nozzles had the same spraying angle $\left(110^{\circ}\right)$ they did not have the same working width (Figure 5). The TT nozzle had a 170 $\mathrm{cm}$ working width, in comparison with the $98 \mathrm{~cm}$ for the DG nozzle. These results indicate that the increase in horizontal spray deposits found in plates 4 and 5 are probably due largely to the spray distribution produced by the nozzle. On the other hand, in the evaluation of the vertical drift, the sprays with the XR and TT nozzles increased it, because the deposits are due to a combination of nozzle spray and drift. tratamiento, ya que con la boquilla AI produjo el mayor depósito (1,0 $\mu \mathrm{g} . \mathrm{cm}^{-2}$ ) en comparación con los otros tratamientos. Sin embargo, no se produjeron diferencias significativas entre las boquillas TT, XR y DG.

En la cuarta placa, a $13 \mathrm{~cm}$ detrás de las plantas, se produjo una disminución del $37,84 \%$ con respecto a la placa 3 , posiblemente debido al efecto barrera de las plantas en este punto. Sin embargo, no se produjeron diferencias significativas en los depósitos producidos por las aspersiones con las boquillas AI, TT y XR $\left(0,35,0,32\right.$ y $0,23 \mu \mathrm{g} . \mathrm{cm}^{-2}$; Figura 3). Guler et al. (2007) obtuvieron resultados similares, señalando que a una velocidad del viento superior a $5,0 \mathrm{~km} \cdot \mathrm{h}^{-1}$ no se produjeron diferencias significativas en los depósitos de las aspersiones con boquillas AI y XR a $0,8 \mathrm{~m}$ de altura sobre un terreno 
Rev. Fac. Agron. (LUZ). 2020, 37: 327-346. Octubre-Diciembre.

Homer et al.

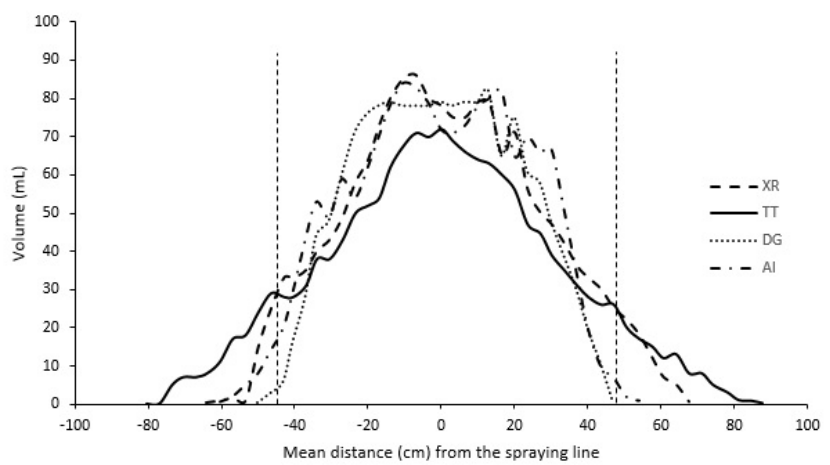

Figure 5. Spray distribution of the nozzles evaluated. The vertical segmented lines indicate the position of the plants.

Figura 5. Distribución de la deriva de las aspersiones con las diferentes boquillas evaluadas. Las líneas segmentadas verticales indican la posición de las plantas.

\section{Conclusions}

A marked decrease is reported in spray deposit when the distance is increased of the application zone, that is downwind of the nozzle.

At plant level, the increase in wind speed of $5.8 \mathrm{~km} \cdot \mathrm{h}^{-1}$ during application, generates a desviation in the path of the smaller droplets produced with conventional nozzle (XR); compared to the droplets generated by the nozzles antidrift TT, DG and AI, generating greater product loss.

At ground level, it was appreciated that with wind conditions, there is an increase in all the nozzles of the tanks before the plant, next to it, and after cultivation, but these did not become statistically significant at this wind level. In addition, the TT nozzle, in a windy condition, presented a decrease in the decrease of its deposits, reaching no differences between the plates. despejado. Sin embargo, la aspersión con la boquilla DG produjo el depósito más pequeño $\left(0,05 \mu \mathrm{g} . \mathrm{cm}^{-2}\right)$.

En la quinta placa, a $21,5 \mathrm{~cm}$ detrás de la planta, se produjeron diferencias estadísticamente significativas entre los tratamientos, debido a los depósitos más grandes producto de las aspersiones con las boquillas TT e AI (0,23 y $0,11 \mu \mathrm{g} . \mathrm{cm}^{-2}$, respectivamente). Las pulverizaciones con las boquillas XR y DG produjeron la menor cantidad de depósitos $(0,05$ y $0,01 \mu \mathrm{g} . \mathrm{cm}^{-2}$, respectivamente), corroborándose nuevamente lo anteriormente explicado.

En general, se produjo una disminución marcada en los depósitos de las aspersiones al aumentar la distancia desde la boquilla de descarga, de acuerdo con Wolf y Frohberg (2002) y Miller et al. (2001). En la placa 4 (13 cm detrás de la planta), se produjo una reducción en $81,1 \%$ de los depósitos con respecto a la placa 1. 
It can be seen that although the angle of $110^{\circ}$ and the height of 35 $\mathrm{cm}$, should have applied up to the plant, this was not the case, finding, in windless conditions, deposits more than $20 \mathrm{~cm}$ after the plant.

\section{End of English Version}

Deriva vertical. Se produjeron diferencias significativas $(\mathrm{p} \leq 0,05)$ entre las dos alturas de aplicación, medidas desde el suelo $(25$ y $50 \mathrm{~cm}$, Figura 4).

En la placa 6 ubicada a $25 \mathrm{~cm}$ sobre el suelo presentó diferencias estadísticamente significativas $(p \leq 0,05)$ entre los tratamientos (Figura 4). Los mayores depósitos fueron originados por las aspersiones con las boquillas XR y TT (0,33 y 0,25 $\mu \mathrm{g} . \mathrm{cm}^{-2}$, respectivamente), seguidas de las boquillas $\mathrm{AI}$ y $\mathrm{DG}$, que produjeron los depósitos más pequeños $(0,16$ y 0,02 $\mu \mathrm{g} . \mathrm{cm}^{-2}$, respectivamente). Esto se debe principalmente a que las boquillas AI y DG reducen el número de gotas finas en comparación con la boquilla plana XR estándar, disminuyendo el efecto de deriva verticalmente. Wilson et al., (2008), indicaron que la boquilla TT reduce significativamente la deriva en comparación con la boquilla DG a una presión de descarga de 1,03 bar.

En la placa 7 ubicada a $50 \mathrm{~cm}$ sobre el suelo, no hubo diferencias significativas entre los tratamientos. Estos resultados coinciden con Guler et al. (2007) en pruebas de túneles de viento a 9 y $18 \mathrm{~km} \cdot \mathrm{h}^{-1}$ con boquillas de aplicación AI y XR. Sin embargo, el menor depósito se produjo con la boquilla DG $\left(0,02 \mu \mathrm{g} . \mathrm{cm}^{-2}\right)$.

En general, se produjo una disminución en los depósitos de las aspersiones a medida que se incrementó la altura de la placa; la placa 6 , ubicada a $25 \mathrm{~cm}$ del suelo, mostró $47,4 \%$ más de depósitos que la placa 7 ubicada a $50 \mathrm{~cm}$ del suelo.

Curvas de distribución de las aspersiones

Aunque todas las boquillas tenían el mismo ángulo de pulverización $\left(110^{\circ}\right)$, no tenían el mismo ancho de trabajo (Figura 5). La boquilla TT tenía un ancho de trabajo de $170 \mathrm{~cm}$, en comparación con los $98 \mathrm{~cm}$ para la boquilla DG. Estos resultados indican que el aumento en los depósitos de las aspersiones encontrados en las placas 4 y 5 probablemente se deba en gran medida al ángulo de descarga de las boquillas. Por otro lado, en la evaluación de la deriva vertical, las aspersiones con las boquillas XR y TT originaron los mayores depósitos debido a la combinación de la forma de descarga de estas boquillas y la deriva originada.

\section{Conclusiones}

Se observó una disminución marcada en los depósitos originados por las aspersiones a favor del viento, cuando se aumenta la distancia desde la zona de aplicación.

A nivel de la planta, el aumento en la velocidad del viento de $5,8 \mathrm{~km} . \mathrm{h}^{-1}$ durante la aplicación, genera una desviación en el camino de las gotas más pequeñas producidas con la boquilla convencional XR generando 
Rev. Fac. Agron. (LUZ). 2020, 37: 327-346. Octubre-Diciembre.

Homer et al.

una mayor pérdida de producto, en comparación con las gotas generadas por las boquillas anti-deriva TT, DG y AI.

A nivel del suelo, se apreció que con las condiciones del viento, hay un aumento en los depósitos localizados antes de las plantas, junto a ellas y detrás de las mismas, producidos por la deriva de las aspersiones con todas las boquillas, a pesar de no mostrar diferencias significativas con la velocidad del viento utilizada.

\section{Literature cited}

Arvidsson, T., L. Bergström and J. Kreuger. 2011. Spray drift as influenced by meteorological and technical factors. Pest Manag. Sci. 67(5), 586598.

Behmer, S., Di Prinzio, A., Striebeck, G. and Magdalena, J. 2010. Evaluation of low-drift nozzles in agrochemical applications in orchards. Chilean J. Agric, Res. 70(3): 498-502.

Bode, L. 1984. Downwind drift deposits by ground applications. Trans. of the ASAE. 35(4):1097-1102.

Boller, W. and J. F. Schlosser. 2010 Consideraciones operativas de las boquillas pulverizadoras. p. 8995. In: Magdalena J, Castillo B, Di Prinzio A, Homer I, Villalba J. (Eds.). Agrochemical application technology. 1er ed. INTA Alto del Valle, Argentina.

Bradford. K. and G. Calvin. 2001. Drift reducing nozzle effects on herbicide performance. Weed Technol. 15(3): 453-460.

Butts, T.R., Samples, C.A., Franca, L.X., Dodds, D.M., Reynolds, D.B., Adams, J.W., Zollinger, R.K., Howatt, K.A., Fritz, B.K., Clint Hoffmann, W. and Kruger, G.R., 2018. Spray droplet size and carrier volume effect on dicamba and glufosinate efficacy. Pest Manag. Sci. 74(9):2020-2029.
Dami, I., B. Bordelon, D. Ferree, M. Brown, M. Ellis, R. Williams and D. Doohan. 2005. Midwest grape production guide. p. 29-31 In: Ohio State University Extension Bulletin 91905, Columbus, Ohio.

Garcerá, C., C. Román, E. Moltó, R. Abad, J. A. Insa, X. Torrent, S. Planas and Chueca, P. 2017. Comparison between standard and drift reducing nozzles for pesticide application in citrus: Part II. Effects on canopy spray distribution, control efficacy of Aonidiella aurantii (Maskell), beneficial parasitoids and pesticide residues on fruit. J. Crop Prot. 94: 83-96.

Guler, H., H. Zhu, E. Ozkan, R. Derksen, Y. Yu and C. Krause. 2007. Spray characteristics and drift reduction potential with air induction and conventional flat-fan nozzles. ASABE 50(3):745-754.

Hardi 2003. Atomization techniques. Hardi publication 673705-E/4. Santiago, Chile. $40 \mathrm{p}$

Jensen, P. K., I. Lund and D. Nuyttens. 2013. Spray liquid distribution and biological efficacy of commercially available nozzles used for precision weed control. Biosyst. Eng. 116(4): 316-325.

Kogan, M. and M. Zúñiga. 2001. Dew and spray volume effect on glyphosate efficacy. Weed Technol. 15(3): 590593.

Linjian J., T. Koch, I. Dami and D. Doohan. 2008. The effect of herbicides and cultural practices on weed communities in vineyards: an Ohio survey. Weed Technol. 22(1):91-96.

Miller, P., A. Hewitt and W. Bagley. 2001. Adjuvant effects on spray characteristics and drift potential. Pesticide Formulations and Application Systems 21:141-151.

Mota, A. 2015. Espectro de gotas e potencial de deriva de caldas contendo o herbicida 2, 4-D amina em misturas em tanque. Botucatu: Universidade Estadual Paulista, 2015. 56p (Doctoral dissertation, Tese Doutorado). Avalaible at: https://repositorio. unesp.br/handle/11449/135920. Accesed date: 15 November 2018. 


\section{Rev. Fac. Agron. (LUZ). 2020, 37: 327-346. Octubre-Diciembre.}

Homer et al.

ODEPA (Office of studies and agrarian policies, Chile) 2017. National record, national information. Avalaible at: https://www.odepa.gob.cl/wp-content/ uploads/2017/06/Ficha-Nacional.pdf. Accesed date: 18 mar.2018.

Oliveira, R. and U. Antuniassi. 2012. Caracterização física e química e potencial de deriva de caldas contendo surfatantes em pulverizações agrícolas. Energia na Agricultura, 27(1), 138-149.

Ormeño, J. 2005. Weeds of fruit orchards and vines: Biology and control. Colección Libros INIA 17. Santiago, Chile. 114 p.

Ozkan, E. and H. Zhu. 2016. Effect of Major Variables on Drift Distances of Spray Droplets. FABE-525. USDA-ARS Application Technology Research Unit.

Palladini, L., C. Raetano and E. Velini. 2005. Choice of tracers for the evaluation of spray deposits. Scientia Agricola 62(5):440- 445.

Planas, S., F. Solanelles, X. Torrent, F. Camp, E. Gregorio and J. Rosell. 2013. Comparing standardized methods for potential drift assessment. p. 26-28. In: Proceedings of the 12th Workshop on Spray Application Techniques in Fruit Growing, Valencia, Spain. Avalaible at: https://www.researchgate.net/ publication/261550507_Comparing_ standardized methods_of potential drift_assessment. Accessed date: $2 \overline{5}$ November 2018.

Prodanova-Marinova, N., E. Tsvetanov and A. Iliev. 2019. Comparative testing of herbicides in newly planted vineyard. Bulgarian Journal of Agricultural Science, 25(1): 109-116.

Prodanova-Marinova, N. and E. Koňova. 2016. Studies on herbicides application in vine nurseries. P: 105-110. In: Scientific proceedings of the 5th International Scientific Horticulture Conference. Avalaible at: https://ves.uniag.sk/files/pdf/ pnhfuvwl4fiarhbcic1iuv9jhiiott. pdf\#page $=105$. Accessed date: 5 July 2018.
TeeJet, 2014. Catalog 51 A-M. Avalaible at: https://www.teejet.com/CMSImages/ TEEJET/documents/catalogs/cat51a metric.pdf. Accessed date: 5 July $201 \overline{8}$

Van de Zande, J., M. Wenneker, J. Michielsen, H. Stallinga, van $P$. Velde and N. Joosten. 2012. Nozzle classification for drift reduction in orchard spraying. Asp. Appl. Biol. 114, 253:260.

Villalba, J., D. Martins, A. Rodríguez and L. Alves. 2009. Effect of types of nozzles on spray deposition on two soybean varieties in stage V3. Agrociencia 43(5):465-473.

Villalba, J. and E. Hetz. 2010. Derivation of agrochemicals and effect of environmental conditions. p.4553. In: Magdalena J, Castillo B, Di Prinzio A, Homer I, Villalba J. (Eds.). Agrochemical application technology. 1er ed. INTA Alto del Valle, Argentina.

VCE Viticulture Consortium East. 2007. Ohio grape research priorities from the Ohio Grape Industries Committee 2007. Rev. 25 July 2018 at: http:// www.nysaes.cornell.edu/adm/ rfpgrapersch/ pdf/Ohio.pdf. Accessed date: 25 November 2018.

Wilson, J., J. Nowatzki and V. Hofman. 2008. Selecting drift-reducing nozzles. Rev. 18 Avalaible at: http://agbiopubs. sdstate.edu/articles/FS919.pdf. Accessed date: 15 December 2017.

Wolf, R. E. and D. D. Frohberg. 2002. Comparison of drift for four driftreducing flat-fan nozzle types measured in a wind tunnel and evaluated using dropletscan software. Paper Number: 021101, ASAE Meeting St. Joseph. 